\title{
IDENTIFIKASI SERANGGA DAN FAKTOR ABIOTIK PERUSAK NASKAH KUNO SEBAGAI UPAYA PELESTARIAN BUDAYA PALEMBANG
}

\author{
Irham Falahudin \\ Prodi Biologi, Fakultas Sains dan Teknologi-UIN Raden Fatah Palembang \\ Email: irhamfalahudin_uin@radenfatah.ac.id
}

\begin{abstract}
The manuscript is one of the relics of the past owned by the people of Indonesia. The manuscript stored a number of past information that shows the thoughts, feelings, beliefs, customs, and values that apply to past societies. Manuscripts are available in various regions in Indonesia, one of them in Palembang. Malay manuscripts are texts written in Malay which are generally Arabic-Malay (Jawi). The existence of this ancient manuscript located in vulnerable society will be damaged. The importance of biological knowledge to this text makes provision for society and government in an effort to keep the extinct. Objectives of the research are to know the form and type of destruction of manuscripts, factors causing damage, to identify the types of biota and insects that destroyed and also how to cope with the presence of insects and biota in Malay manuscript storage. The research with a descriptive quantitative approach. The sampling of insects and biota by hand collecting method. Identified insect use to morphometric technique. The results are found 11 species of insects from 5 orders and 6 families. Cause damage to manuscripts in Palembang include as physical and chemical factors. Processes causing the destruction of manuscripts include biological factors
\end{abstract}

Keyword: Identification Insect and abiotic factors, Manuscript Malay in Palembang

\section{PENDAHULUAN}

Produk budaya melayu Islam di nusantara dalam bentuk tradisi tulis disebut dengan naskah (Manuscript). Naskah kuno melayu di Indonesia banyak tersebar luas di beberapa wilayah nusantara. Produk naskah ini banyak ditulis dengan aksara daerah dan sudah berkembang dengan aksara arab melayu. Sebagian besar naskah kuno tersebut berusia ratusan tahun lebih sehingga mudah rusak apa bila digunakan. Hal ini disebabkan oleh banyaknya naskah disimpan yang disimpan secara pribadi.

Naskah kuno atau manuskrip telah diatur pengelolaannya dalam UndangUndang Nomor 5 Tahun 1992 tentang Benda Cagar Budaya dan Undang-Undang Nomor 19 Tahun 2002 tentang Hak Cipta, sehingga keberadaan hasil budaya bangsa/ naskah kuno ini tetap aman, terjaga dan terlindungi, serta tidak mudah 
berpindah pengelolaannya oleh pihak-pihak lain. ${ }^{1}$ Pengelolaan naskah kuno yang dimaksud dalam undang-undang tersebut salah satunya adalah upaya untuk melestarikannya. Pelestarian (Preservation) ini yakni baik dari faktor ancaman terhadap adanya praktek jual beli naskah-naskah kuno maupun ancaman dari faktor kerusakan yang disebabkan oleh lingkungan alam yang ada di wilayah tempat penyimpanan naskah kuno tersebut.

Salah satu wilayah yang dikenal sebagai tempat penyalinan naskah-naskah Melayu serta sebagai salah satu yang dikenal sebagai pusat sastra Melayu pada abad XVIII adalah di Palembang, ${ }^{2}$ sehingga Palembang dikenal sebagai salah satu 'Skriptorium' (tempat penyalinan naskah) terbesar pada masanya yakni pada masa Kesultanan Palembang. Naskah-naskah Melayu yang masih tersimpan di Palembang hingga saat ini adalah sebagai bukti adanya jejak-jejak kecemerlangan intelektual Islam pada masa lalu yang dilakukan oleh para ulama-ulama terdahulu maupun para penguasa Palembang pada masa tersebut.

Jejak kecermelangan intelektual Islam di Palembang dapat ditelusuri dari figur-figur penguasa maupun Ulama-ulama. Memasuki abad XVIII di Palembang terdapat nama Syekh Abdus Samad Al-Palimbani yang memiliki reputasi intelektual internasional dengan puluhan karya-karya terkenalnya. ${ }^{3}$ Selanjunya pada abad XIX-XX muncul ulama-ulama penulis lainnya yang menghasilkan banyak karya-karya, diantaranya adalah: Syekh Muhammad 'Aqib bin Hasanuddin , Syekh Muhammad Azhari bin Abdullah (1811-1874 M), Muhammad Azhari bin Abdullah bin Ma'ruf (1856-1932 M), Abdullah bin Muhammad Azhari (1854-1937 M). ${ }^{4}$

Banyak sekali karya-karya para intelektual Islam Palembang yang ditinggalkannya, dan sampai saat ini karya-karya tersebut selain disimpan di beberapa lembaga resmi yakni: Museum Balaputera Dewa dan Museum Mahmud Badaruddin II, namun demikian kebanyakan justru tersimpan oleh sebagian masyarakat yang didapatkannya secara turun temurun. Di antara pemilik dan penyimpan naskah-naskah kuno di Palembang tersebut antara lain adalah: Kemas Andi Syarifuddin, Idrus al Munawar, Sayid Alwi Assegaf, Haji Ahmad Fauzi, Mualim Nang/Ali Ahmad Bahsein (Yayasan Darul Aitam), Kiai Haji Abdullah Azhari, Muhammad Djufri, Syafei Prabu Diraja, Ustaz Ending, Sayyid Abdullah Alkaf, Muhammad Zen Syukri, Salman Ali, Abdul Azim Amin, Muhammad Akib, Reza Pahlevi, Nyimas Laily Yunita, dan Baba Haji Mahmoed Abbas, Haji Muhammad Zainuddin Syawaluddin, dan Surip Suwandi. ${ }^{5}$

${ }^{1}$ Undang-Undang No. 5 Tahun 1992 tentang Benda Cagar Budaya, Bab I Pasal 2.

2 Maria Indra Rukmi, "Penyalinan Naskah Melayu Palembang: Upaya Mengungkap Sejarah Penyalinannya", dalam Jurnal Wacana Volume 7 No. 2 Tahun 2005, hlm. 149-160.

3 Diantara karya-karyanya yang terkenal telah di cetak beberapa kali di Mesir maupun di Surabaya, dan telah beredar juga di Malaysia maupun Negara-negara lain. Lihat juga dalam Feener, R. Michael "Abd al-Samad in Arabia: The Yemeni Years of a Shaykh from Sumatra", Southeasth Asian Studies Vol. 4 No. 2 (Singapore: Center For Southeast Asian Studies Kyoto University (2015), hlm. 259-277. http://hdl.handle.net/2433/199719.

${ }^{4}$ Zulkifli, Ulama Sumatra Selatan : Pemikiran dan Peranannya Dalam Lintasan Sejarah. (Palembang: Unsri Press, 1999), hlm. 11-40.

5 Tim Penyusun, Katalog Naskah Palembang, (Jakarta: Yayasan Naskah Nusantara (Yanassa) dan Tokyo University of Foreign Studies (TUFS) Jepang, 2003). 
Sementara itu dari informasi Katalog Naskah Palembang juga dapat diketahui bahwa lebih kurang sebanyak 215 manuskrip asal Palembang, Sumatera Selatan, telah diinventarisir pada tahun 2003 oleh Yayasan Naskah Nusantara (Yanassa). Naskah kuno sebagai warisan intelektual dan budaya tersebut sebagian besar ditulis sekitar abad 18-19 Masehi pada masa Kesultanan Palembang Darussalam. ${ }^{6}$ Manuskrip-manuskrip tersebut sebagian besar adalah membicarakan berbagai tema keagamaan, seperti tasawuf, tafsir, sejarah, hadis, dan suratmenyurat. Berdasarkan pengamatan dengan cara observasi awal ke beberapa penyimpan naskah kuno, ternyata masih banyak manuskrip lainnya yang belum diinventarisir dan masuk dalam katalog. Naskah-naskah tersebut sebagian besar masih disimpan di rumah masyarakat Palembang khususnya dan masyarakat Sumatera Selatan pada umumnya.

Setelah melakukan penelitian awal tersebut, peneliti merasa prihatin dengan keadaan naskah-naskah kuno yang tersimpan pada masyarakat pemilik naskah di Palembang. Banyak naskah kuno yang rusak seperti berlubang-lubang pada kertas maupun sampulnya, serta banyak naskah yang kertasnya dimakan tinta. Beberapa bagian naskah pun sudah tidak utuh karena berlubang, bahkan ada sebagian yang tulisannya dimakan tinta sehingga teksnya menjadi tidak bisa lagi terbaca. Sehingga sangat disayangkan akan keberadaan naskah kuno yang memiliki nilai historis tinggi tersebut akan terancam semakin rusak. Padahal penyimpanan naskah-naskah kuno mestinya ada perlakuan khusus. Naskah kuno seharusnya disimpan di ruangan khusus yang terjaga kelembaban dan sirkulasi udaranya sehingga terhindar dari serangan biota maupun serangga yang bisa menjadi sebab adanya kerusakan naskah kuno.

Naskah kuno merupakan warisan budaya yang patut dilestarikan. Namun demikian kenyataannya yang ada di Palembang saat ini, masyarakat pemilik dan penyimpan naskah banyak yang kurang memperoleh informasi bagaimana sebaiknya merawat dan memperlakukan naskah kuno dengan baik dan benar. Pada akhirnya, naskah kuno yang ada di Palembang ini akan terancam hancur atau rusak. Bahkan sampai saat ini juga dikhawatirkan naskah-naskah kuno yang ada di Palembang ini bisa berpindah tangan, dari masyarakat pemilik kepada pihak asing, yang kemudian mengklaim sebagai warisan budaya milik mereka.

Naskah Kuno atau Manuskrip adalah dokumen dalam bentuk apapun yang ditulis dengan tangan atau diketik yang belum dicetak atau dijadikan buku tercetak yang berumur 50 tahun lebih (UU Cagar Budaya No. 5 Tahun 1992, Bab I Pasal 2). Naskah kuno terdiri dari beberapa komponen antara lain: kertas, tinta dan komponen-komponen untuk menjilid seperti kertas karton, plastik, tekstil, benang, paku, dan perekat. Umumnya komponen-komponen yang digunakan baik unsur kertas, karton dan perekat mengandung asam.

Ratusan jenis biota khususnya serangga hidup dengan sumber makanan yang berasal dari naskah kuno, karena makanan utamanya adalah kertas dan zatzat yang ada dalam kertas. Akibatnya naskah kuno rentan akan adanya serangan

${ }^{6}$ Tim Penyusun, Katalog Naskah Palembang, (Jakarta: Yayasan Naskah Nusantara (Yanassa) dan Tokyo University of Foreign Studies (TUFS) Jepang, 2003). 
biota maupun serangga yang bisa mengakibatkan naskah kuno menjadi berlubang, lapuk, rusak dan tidak bisa digunakan lagi.

Sayangnya, sampai sekarang belum ada pihak-pihak (instansi pemerintahan daerah maupun pusat maupun para akademisi) yang memperhatikan masalahmasalah yang mengancam keberadaan naskah-naskah kuno yang ada di Palembang. Adanya ancaman berupa kerusakan naskah yang disebabkan serangan biota, serangga buku, kurangnya pengetahuan pemilik dan penyimpan naskah kuno terhadap cara pelestarian melalui perawatan maupun ancaman terhadap adanya praktek jual beli naskah-naskah kuno. Selain itu juga belum banyak dari unsur akademisi yang konsen untuk melakukan kajian terhadap keberadaan naskah-naskah kuno Palembang baik dari telaah ilmu Filologi maupun dari perspektif keilmuan lainnya, khususnya dari Perspektif Ilmu Biologi (Ekologi dan Entomologi). Cabang Ilmu Biologi khususnya pada kajian Entomologi selayaknya juga ikut serta mengambil peran dalam upaya melestarikan warisan inteletual para ulama Palembang berupa naskah-naskah kuno. Kemudian ilmu ekologi juga mempunyai peranan penting untuk pelestarian dan perlindungan naskah kuno.

Pentingnya dilakukan penelitian pengembangan keilmuan ini adalah mengingat kondisi naskah-naskah kuno di Palembang saat ini dipandang sangat memprihatinkan dengan kondisi kerusakannya. Kerusakan ini selain proses penyimpanan secara fisik juga disebabkan oleh faktor biologis seperti biota dan serangga buku dan kimiawi seperti tinta dan keasaman $(\mathrm{pH})$. Penelitian ini juga diharapkan dapat memberi kontribusi bagi pengkaji selanjutnya dalam upaya melestarikannya baik melalui konservasi, restorasi maupun digitalisasi.

Penelitian tentang biota dan serangga yang menjadi salah faktor dapat merusak naskah-naskah kuno di Palembang, berdasarkan dari pengamatan dan penelusuran peneliti hingga kini belum ada yang melakukannya. Demikian juga penelitian dengan obyek naskah kuno di Palembang, juga belum ada yang melakukan dengan menggunakan perspektif dari ilmu Biologi khususnya ekologi. Padahal obyek naskah-naskah kuno juga bersinggungan dengan ilmu Biologi, khususnya tentang keberadaan 'Biota dan Serangga" yang dapat mengancam terjadinya kerusakan pada naskah-naskah kuno tersebut.

Namun demikian, di Jawa ada beberapa kajian yang telah dilakukan oleh beberapa orang dalam rangka penyelesain studi S1 maupun S2 dalam bidang Ilmu Perpustakaan dan Informasi. Kajian tersebut antara lain adalah: Febri Arianti Astuti (2010) dengan judul "Studi Tentang Pelestarian Naskah Kuno Dan Penanggulangannya di Perpustakaan Dewantara Kirti Griya taman Siswa Yogyakarta". D Dalam kajiannya Febri menyebutkan salah satu faktor adanya kerusakan bahan pustaka di perpustakaan tersebut adalah dikarenakan faktor Biologi, namun demikian ia tidak menyebutkan secara rinci jenis-jenis serangga maupun biota lainnya. Selain itu identifikasi jenis serangga yang terdapat di wilayah kajian juga tidak dilakukannya. Kajian penelitian lainnya Scheper (2013), laporan penelitiannya melihat tiga fitur mengikat sangat spesifik, pengaturan

${ }^{7}$ Febri Arianti Astuti, "Studi Tentang Pelestarian Naskah Kuno Dan Penanggulangannya di Perpustakaan Dewantara Kirti Griya taman Siswa Yogyakarta" dalam Skripsi Jurusan Perpustakaan Dan Informasi, Fakultas Adab dan Ilmu Budaya UIN Sunan Kalijaga, Yogyakarta, 2010. 
cahaya baru pada struktur naskah Islam melayu ${ }^{8}$. Kajian lainnya dilakukan oleh Dinar Puspita Dewi (2014) dengan judul "Preservasi Naskah Kuno: (Studi Pada Perpustakaan Reksa Pustaka Pura Mangkunegaran Surakarta)". 9 Dalam kajiannya Dinar juga menyebutkan salah satu faktor yang menyebabkan kerusakan pada naskah kuno di Perpustakaan Reksa Pustaka adalah faktor Biologi, yakni sebesar $37 \%$. Namun demikian Dinar tidak menyebutkan bagaimana biota dan serangga jenis apa saja identifikasinya juga tidak ada.

Keseluruhan penelitian yang disebutkan di atas akan dijadikan referensi informasi. Hal tersebut berguna untuk menunjukkan adanya keterkaitan dan pendahuluan pengkajian yang telah dilakukan oleh para ilmuwan dan peneliti sebelumnya pada bidang yang sama sama yakni 'naskah kuno' meskipun dengan perspektif atau pendekatan yang berbeda. Dengan demikian, diharapkan penelitian ini dapat menampilkan sesuatu yang berbeda dengan sejumlah karya yang telah ada, sekaligus bisa memberikan kritik terhadap karya karya tersebut melalui penelitian ini.

Pentingnya penelitian ini untuk segera dilakukan dengan harapan hasilnya akan dapat dijadikan sebagai informasi awal yang sangat berharga dalam pelestarian naskah kuno melayu di Indonesia umumnya, Sumatera Selatan khususnya kota Palembang. Hasil penelitian ini dapat dijadikan sebagai bahan dasar kebijakan bagi instansi terkait untuk melestarikan warisan inteketual ulama Palembang dalam upaya untuk segera melakukan langkah-langkah kegiatan konservasi, restorasi maupun digitalisasi terhadap naskah-naskah kuno di Palembang. Permasalahan diatas lebih konkritnya adalah bagaiman mengidentifikasi jenis serangga dan biota yang merusak naskah kuno Palembang dan bagaimaa cara penanggulangannya serta faktor apasajakah penyebab kerusakan naskah tersebut selain faktor biologis tadi. Secara umum penelitian bertujuan untuk ikut serta melestarikan kandungan informasi dari isi teks naskahnaskah kuno di Palembang sebagai warisan intelektual para ulama. Sebagai usaha penyelamatan dan mengupayakan dalam menjaga warisan intelektual para ulama Palembang. Memberi data-data tentang penyebab kerusakan naskah-naskah kuno di Palembang sebagai dasar kebijakan bagi instansi terkait dalam upaya melestarikan warisan inteketual ulama Palembang dengan cara melakukan konservasi, dan restorasi terhadap naskah-naskah kuno di Palembang. Kemudian Memberi data-data spesifikasi jenis-jenis biota dan serangga yang mengancam keberadaan naskah kuno di Palembang, untuk selanjutnya dapat dimanfaatkan oleh mahasiswa jurusan Biologi guna kepentingan kajian ilmiah lainnya. Pada tujuan khususnya penelitian ini diharapkan memberikan pengetahuan tentang bentuk dan jenis kerusakan naskah-naskah kuno di Palembang. Selain itu juga untuk melihat dan mengetahui faktor-faktor penyebab kerusakan pada naskah kuno di Palembang. Melakukan identifikasi jenis serangga dan biota yang merusak naskah kuno di Palembang, serta mengidentifikasi jenis biota dan

${ }^{8}$ Scheper , K. .2013. Three very specific binding features, shedding new light on Islamic manuscript structures. Journal of Islamic Manuscripts, vol. 4,(1) pp. 82-109.

${ }^{9}$ Dinar Puspita Dewi, "Preservasi Naskah Kuno: (Studi Pada Perpustakaan Reksa Pustaka Pura Mangkunegaran Surakarta)" dalam Tesis Konsentrasi Ilmu Perpustakaan Dan Informasi Program Pascasarjana, UIN Sunan kalijaga Yogyakarta, 2014. 
serangga yang akan menjadi ancaman terjadinya kerusakan pada naskah-naskah kuno di Palembang. Kemudian pada akhirnya akan dapat melakukan bagaimana menanggulangi terhadap kehadiran biota dan serangga di tempat penyimpanan naskah-naskah melayu Palembang, serta bagaimana faktor-faktor dan prosesproses penyebabnya. Oleh karena itu kajian integrasi keilmuan biologi dan filologi ini dapat dijadikan sebagai bentuk penelitian pengembangan untuk melesatarikan naskah di kota Palembang.

\section{MATERIAL DAN METODE}

Penelitian ini telah dilaksanakan pada bulan Mei sampai dengan Bulan Oktober 2017 bertempat di Kota Palembang. Penelitian ini merupakan kajian Ekologi Hewan dengan fokus kajian tentang serangga (entomologi) dan terkoneksi dengan ilmu Filologi (kajian naskah kuno). Data dalam penelitian ini adalah menggunakan data primer yaitu data dari sumber utama berupakan serangga dari tempat penyimpan naskah di Kota Palembang. Pengambilan sampel menggunakan metode pusposive sampling pada pemilik naskah. Sampel biota dan serangga diambil secara acak berdasarkan ada tidaknya biota dan serangga pada naskah yang diteliti.

Pada penelitian ini menggunakan alat sebagai berikut: kuas ukuran $1 \mathrm{~cm}$, $5 \mathrm{~cm}$ dan kuas lukis, cawan petridish, alkohol 70\%, botol sampel, camera digital, mikroskop binokuler, mikroskop stereo, kertas putih, kertas saring, lem, lup, optik lab, penggaris, $\mathrm{pH}$ indikator universal, cawan kaca, pinset, formalin $4 \%$, jarum ose, jarum insect, kertas label, alat tulis. Adapun bahan yang digunakan antara lain: naskah-naskah melayu kuno Palembang, kumbang (serangga) yang ditemukan. Pada penelitian ini, penulis menggunakan metode deskriptif kuantitatif yaitu mencoba memberikan gambaran keadaan masa sekarang secara mendalam terhadap kerusakan naskah dengan tujuan mendeskripsikan secara sistematis, faktual dan akurat mengenai fakta dan sifat populasi serangga yang terdapat pada naskah kuno dan menggambarkannya secara detail.

1. Di lapangan

Adapun langkah kerja di lapangan sebagai berikut:

a) Peneliti mencari beberapa naskah melayu kuno Palembang yang tersimpan di masyarakat kota Palembang dan musium SMB/Balaputra Dewa kota Palembang. Naskah yang ditemukan selanjutnya di foto dan diidentifikasi keadaan naskahnya.

b) Mengukur faktor abiotik yaitu temperatur penyimpanan, cahaya, mengukur $\mathrm{pH}$ kertas pada tempat penyimpanan naskah.

c) Naskah yang diamati dalam kondisi rusak tersebut diinventaris dengan pemberian label dan nomor. Naskah diamati dan dibersihkan untuk mendapatkan sampel serangga yang masih tersisa pada naskah tersebut dengan menggunakan kuas $5 \mathrm{~cm}$ dan kaca pembesar (lup).

d) Naskah yang dibersihkan tersebut, sapuannya dialas dengan kertas karton putih. Hasilnya dimasukkan kedalam botol sampel yang telah diberikan larutan alkohol $70 \%$ dan formalin $4 \%$ kemudian diberi label sesuai kode naskahnya. 
e) Sampel serangga yang ditemukan, selanjutnya dibawa ke laboratorium Biologi UIN Raden Fatah Palembang untuk diidentifikasi.

\section{Di laboratorium}

Setelah dari lapangan, serangga yang ditemukan pada naskah tersebut diidentifikasi serangga (Booth, R.G., et.al, 1989) dengan langkah-langkah sebagai berikut:

a) Sampel serangga di sortir dan dibuat spesimen master jenis serangga yang ada di naskah-naskah Melayu Palembang.

b) Melakukan inventarisasi dan identifikasi di laboratorium. Jenis biota dan serangga yang didapat kemudian diamati dibawah mikroskop untuk diidentifikasi secara morphometrik dan di foto menggunakan kamera digital dan optic lab.

c) Sampel yang didapatkan selanjutnya dibuat deskripsi untuk dianalisis dampak negatif biota dan serangga tersebut pada naskah kuno yang tersimpan di Palembang.

d) Langkah terakhir adalah spesimen biota dan serangga yang ditemukan selanjutnya diawetkan dengan membuat insektarium. Hasil disimpan laboratorium Biologi UIN Raden Fatah Palembang, yang diharapkan kedepannya dapat berguna bagi keperluan penelitian mahasiswa, dosen, maupun keperluan akademik lainnya.

\section{HASIL}

1. Bentuk dan Jenis Kerusakan serta Prosentase Kerusakan pada NaskahNaskah Kuno Di Palembang

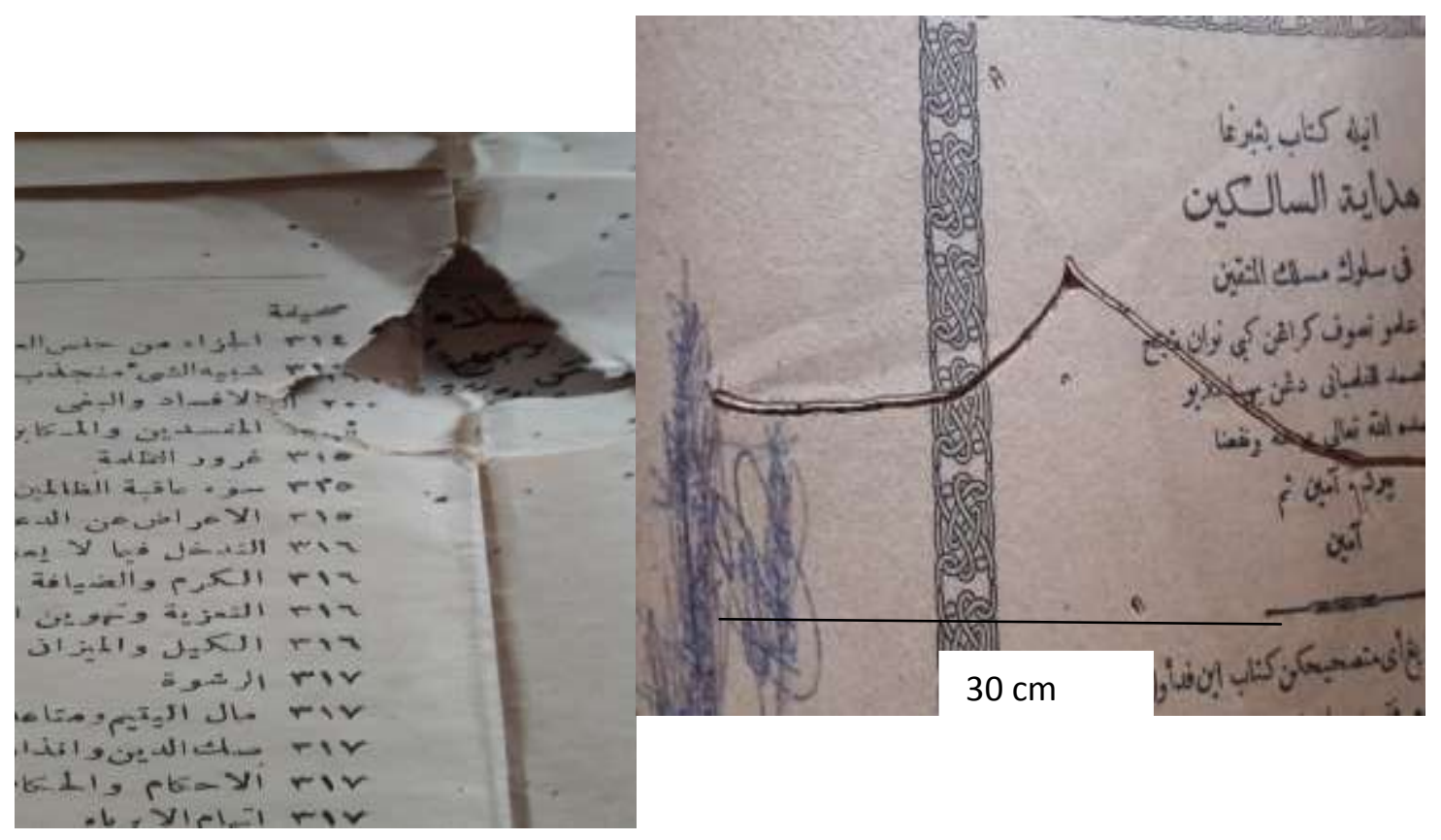


Sumatera Selatan adalah satu diantara provinsi di Indonesia yang terletak di bagian selatan pulau Sumatera. Secara geografis Sumatera Selatan berbatasan dengan provinsi Jambi, diutara dengan provinsi kepulauan Bangka Belitung, di selatan dengan provinsi Lampung dan di bagian barata dengan provinsi Bengkulu. Ibu kota provinsi Sumatera Selatan dengan ibukota Palembang, telah terkenal sejak dahulu karena menjadi pusat kerajaan Sriwijaya. Provinsi Suamtera Selatan sejak berabad yang lalu dikenal juga dengan sebutan Bumi Sriwijaya,pada abad ke VII, merupakan pusat kerajaan Sriwijaya yang terkenal dengan kerjaan maritim. Sejak abad ke XIII-XIV, wilayah ini berada di kekuasaaan Majapahit. Pada awal abad ke XV, berdirilah kesultanan Palembang yang berkuasa sampai datangnya kolonialisme Belanada (Igama, 2015).

Sematera Selatan secara garis besar memiliki semiblan buah sungai besar. Sungai menjadi bagian penting dalam proses aktvitas kehidupan sehari-hari, sehingga budayanya dikenal dengan istilah "batang hari sembilan". Kebudayaan Sumatera Selatan dapat diidentifikasi berdasarkan arus sungai. Pada bagian sumber mata air atau daerah pedalaman dinamakan wilayah ulu (uluan), sedangkan yang dekat muara disebut hilir. Dengan sistem kebudayaan ini terbentuknya keragaman produksi budaya berdasarkan wilayah uluan, dan dinamika kebudayan besar diwilayah ilir. Terdapat dua bahasa besar di Sumatera Selatan yaitu bahasa komering dan bahasa Melayu dengan masing-masing dialeknya. Kenyataan kebahasaan ini memberi pengaruh kuat kepada surat atau naskah kebudayaan tradisi tulis kaganga di daerah uluan (Igama, 2015).

Naskah kuno dimaksudkan ini adalah naskah yang masih ditulis tangan atau karangan seseorang sebagai karya asli (KBBI, 2015). Naskah adalah benda peninggalan dalam bentuk tulisan tangan yang berisi berbagai aspek kehidupan yang dikemukakannya seperti maslah sosial, politik, ekonomi, agama, kebudayaan, bahasa dan sastra. Apabila dilihat dari sifat pengungkapannya dapat dikatakan bahwa, isinya mengacu kepada sifat-sifat historis, didaktis dan religius (Barried, 1985). Naskah secara umum adalah tulisan tangan. Naskah asli merupakan teks induk yang dibuat oleh pengarang sendiri atau diakui sebagai naskah asal (Zaidan, dkk. 1994). Naskah kuno merupakan warisan dari sebuah peradaban manusia yang memiliki nilai peradaban manusia yang memiliki nilai informasi yang termuat dalam naskah tersebut. Apabila dibandingkan dengan benda cagar budaya lainnya, naskah kuno memang lebih rentan rusak akbiat kelembaban udara, air, oleh hewan dan biotalainnya, ketidak pedulian, kebakaran, pencurian, bencana alam dan aktivitas jual beli naskah ke mancanegara. Masih banyak naskah-naskah di Nusantara khususnya di Sumatera Selatan lebih sempit lagi di kota Palembang terabaikan. Cara penyimpanan yang hanya disimpan ala kadarnya dalam lemari tanpa pengaman atau tanpa pengawet apapun. Bahkan ada naskah kuno yang rusak atau robek dan ditambal dengan kertas lain untuk memperekatkan kembali robekan tersebut (Permadi, 2011).

Gambaran naskah kuno di kota Palembang ada beberapa tempat yang ditemui dan kebanyakan adalah pemilik naskah individual yang didapatkan secara turun temurun diwariskan oleh pendahulunya. Ada beberapa naskah kuno 
ditemukan di kota Palembang seperti didaerah kampung Kapiten, kampung arab dan di musium. Ada juga beberapa pesantren yang masih memiliki naskah-naskah kuno tersebut yang sifatnya pribadi.

Dari hasil penelitian yang didapatkan kebanyakan naskah yang difoto rusak akibat diserang oleh serangga pemakan kertas (Ortoptera dan Coleoptera), biota lain seperti jamur. Selain itu karena rusak akibat penyimpanan dan lapuknya bahan akibat tidak terawat.

Pada Gambar 1 dan 2 terlihat kerusakan akibat zat kimia dari penggunaan tinta, selain itu jamur akibatnya kertas naskah menjadi berlobang. Pada Gambar 1 dan 2 kelihatan kumbang pengerek kertas yang mampu melobangi kertas yang tebal tersebut sehingga ada beberapa bagian tidak terbaca. Disatu sisi jamur, dengan bercak-bercak hitam yang terdapat dipinggiran naskah. Pada Gambar 1 dan 2, terlihat kondisi naskah berlobang, seperti bor. Hal ini disebabkan oleh kumbang perusak buku yang mampu membuat lubang seperti bor. Lubang ini menembus ke halaman selanjutnya. Kerusakan oleh kumbang ini hampir semua kertas bolong dan berlubang. Kemampuan makan ini disebabkan oleh kertas memiliki kadar selulose yang memungkinkan kumbang tersebut untuk memakannya. Pada gambar 4 juga terlihat bercak hitam yang disebabkan kertas lembab sehingga memudahkan jamur untuk tumbuh dan berkembang dengan baik.

Hasil yang didapatkan hampir $80 \%$ naskah dimakan dan terdapat lubang pada setiap lembar naskah yang disebabkan oleh kumbang, rayap. Pada gambar 3 dan 4 terdapat jalur yang dibuat oleh rayap dan lubang oleh kumbang kertas. Panjangnya sama dengan lebar buku. Kelihatan kalau naskah ini cocok bagi tempat rayap karena pemeliharaan yang kurang terawat. Naskah yang ditemukan pada pemilik naskah hampir semuanya rusak. Katagori yang dilihat adalah adanya lembaran naskah yang berlubang dan rusak pada setiap lembaran.

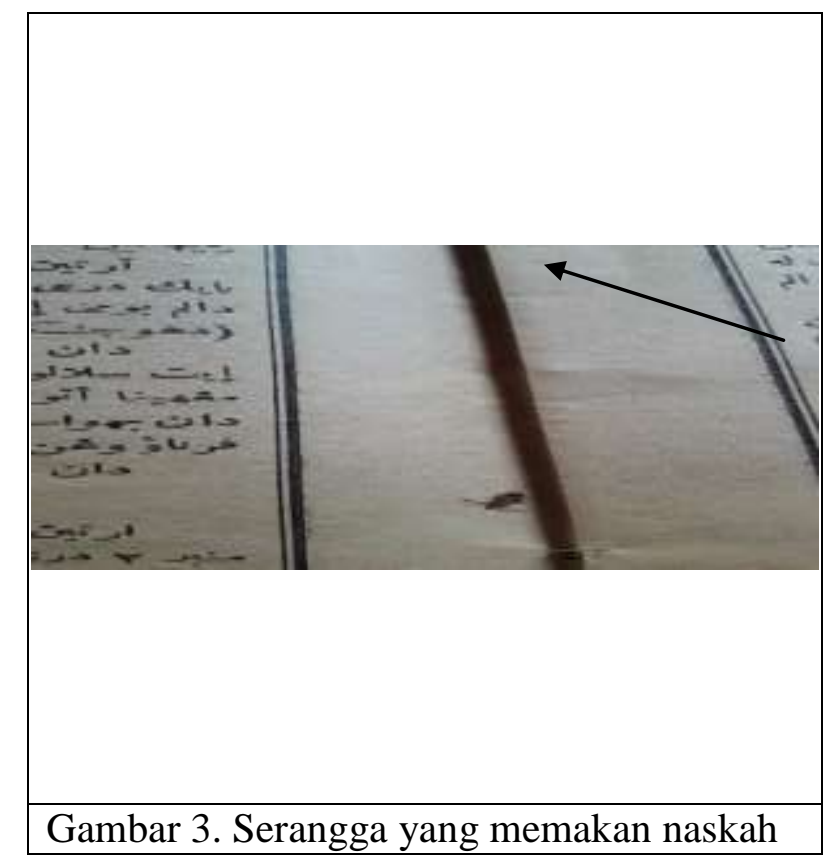


Hasil lain didapatkan pada gambar 3 kumbang yang mati terdapat didalam naskah kuno yang dikoleksi dari survey per lembar naskah. Serangga ini merusak naskah dengan cara memakan dan membuat lubang. Terdapat pada sudut-sudut lipatan naskah yang membuatnya aman dari cahaya dan sumber makanan yang cukup sehingga mampu hidup didalam naskah kuno tersebut.

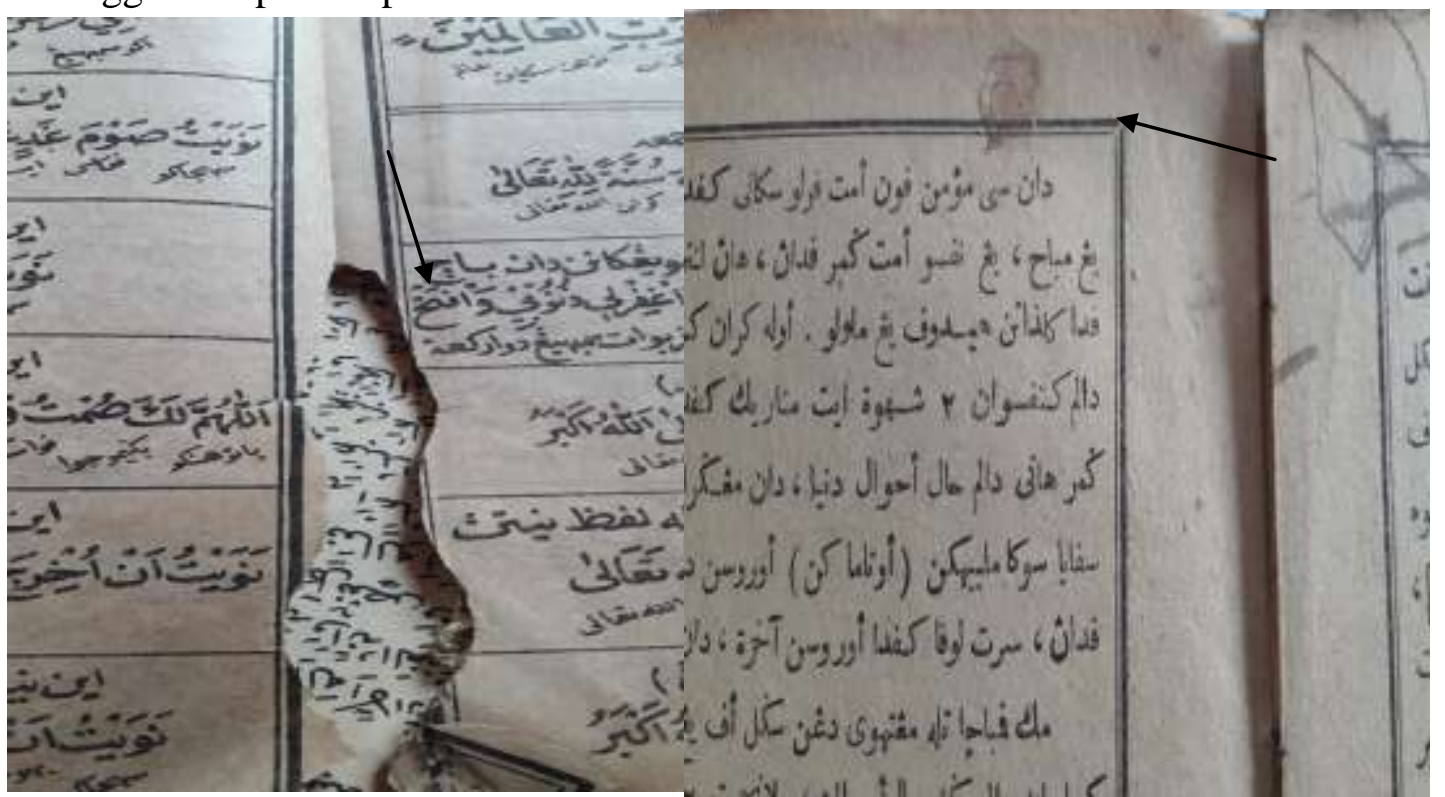

Gambar 4. Naskah yang dimakan Gambar 5. Jamur pada sisi atas naskah serangga lebih dari $10 \mathrm{~cm}$

Pada gambar 4 terlihat serangga membuat naskah menjadi rusak dan hampir tidak terbaca karena dimakan oleh serangga (rayap, kumbang). Gambar 5 lembar naskah lapuk karena munculnya jamur pada area tersebut. Hal ini disebabkan karena lemari penyimpanan lembab dan faktor sirkulasi dan cahaya yang tidak cukup.

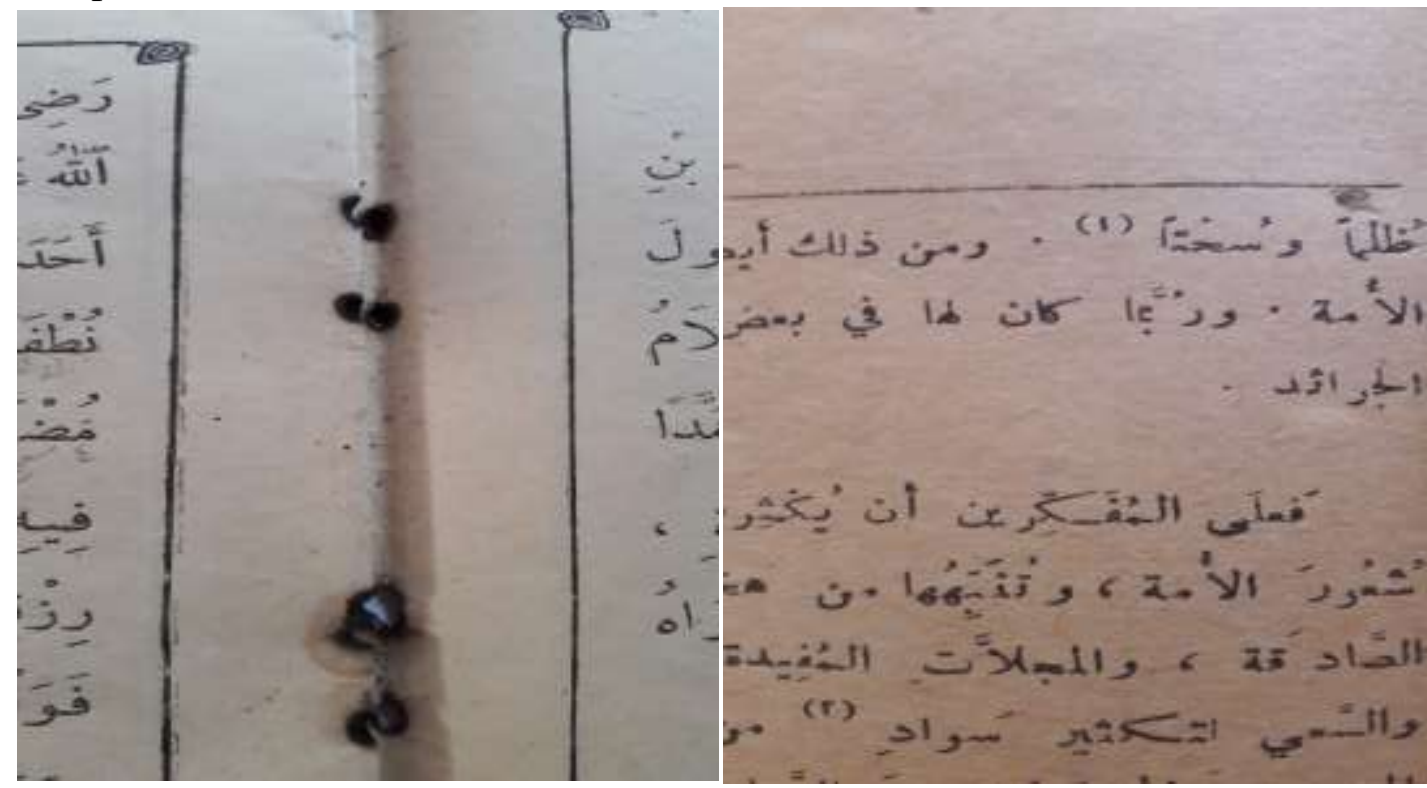

Gambar 6. Kerusakan akibat zat kimia

Gambar 7. Kerusakan akibat jamur 
Faktor biologi yang menyebabkan terjadinya kerusakan pada arsip banyak ditemui pada daerah tropis. Faktor biologi antara lain bisa dari serangga, atau dari sejenis jamur. Untuk masalah jamur ini sangat dibutuhkan perhatian yang cukup besar, Dikarenakan penyebab tumbuhnya jamur oleh bakteri yang sukar dilihat secara kasat mata, oleh karena itu perlu perhatian khusus untuk arsip yang menggunakan bahan kertas. Timbulnya jamur bisa menyebabkan pembusukan pada selulosa (sejenis tanaman) dan bahan kertas. Gejala awal terjadinya pembusukan pada kertas dapat dilihat pada warna kuning dikertas (Gambar6 dan 7), berikutnya berubah menjadi kecoklatan dan akhirnya kertas berwarna hitam. Hebatnya lagi jamur bisa merusak pelekat (lem) dan dapat pula melekatkan kertas satu dengan lainnya.

Jamur dapat tumbuh disebabkan oleh kondisi lingkungan, yang lembab, temperatur, serta pencahayaan yang minim. Faktor yang lebih dominan dalam tumbuh dan berkembangnya jamur adalah kelembaban dan temperatur. Untuk faktor lain yang menyebabkan tumbuhnya jamur bisa disebabkan oleh kondisi ruangan yang kurang terang (redup) dan juga kelembaban suhu ruangan di atas 0\% .Tumbuhnya jamur ditandai dengan bintik bintik hitam atau coklat pada kertas, dan itu bisa dilihat pada kertas-kertas yang telah berumur cukup lama. Bintik bintik hitam itu sebagai dari akibat dari terjadinya reaksi kimia yang terkandung pada kertas bercampur dengan asam organik yang dikandung oleh jamur

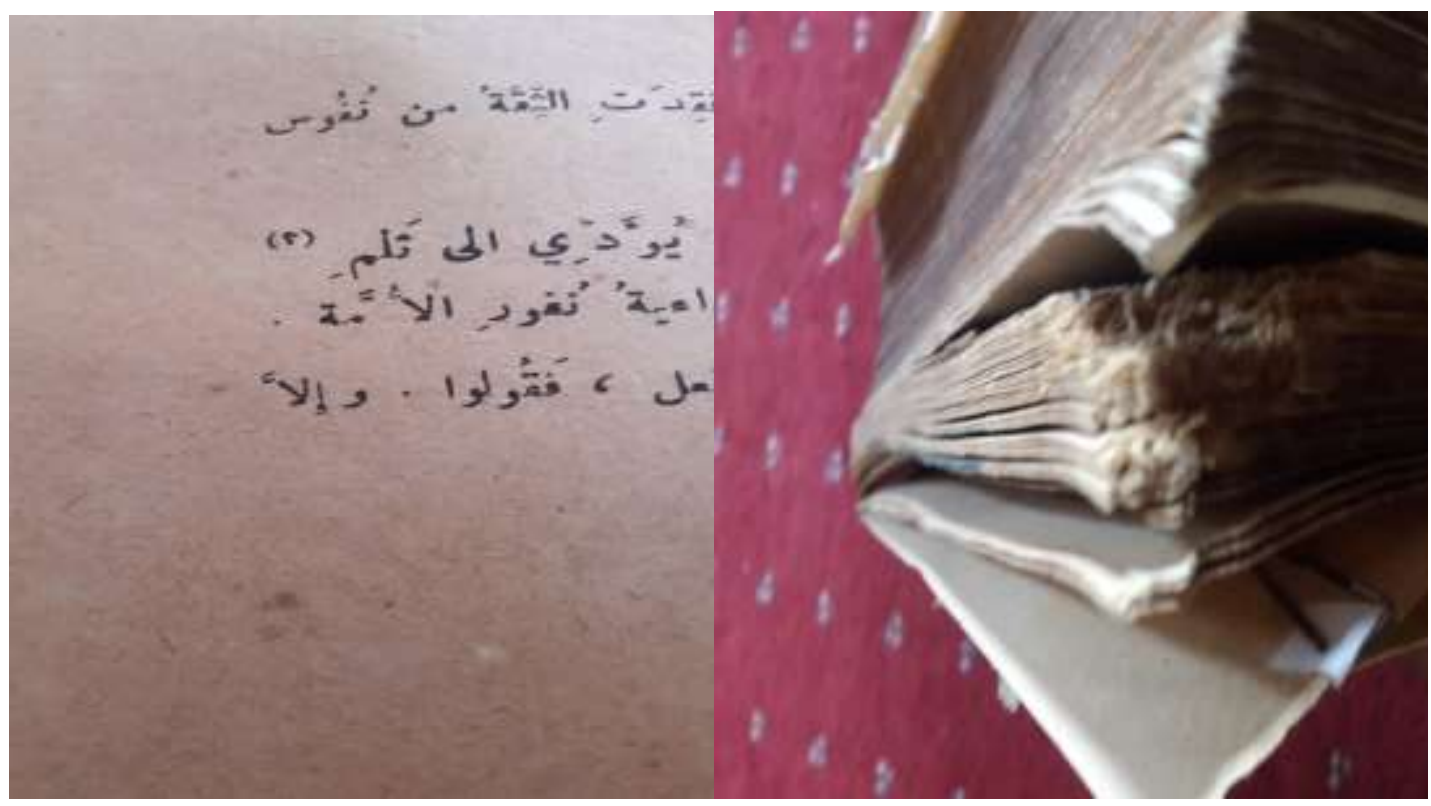

Gambar 8 dan 9 Serangga memakan sisi tepi naskah

Faktor penyebab lain dari kerusakan kertas (Ganbar 8 dan 9) bisa disebabkan dari kertas itu sendiri. Misalnya kertas yang memang sudah mengandung asam sejak awal kertas diproses di Paberik pembuatan kertas. Jadi kemungkinan suatu arsip yang sudah dirawat dengan baik, tetapi masih juga terjadi kerusakan, hal itu bukan karena pengaruh adanya jamur, serangga, atau 
pencemaran, tetapi disebabkan dari bahan baku kertas itu yang sudah mengandung asam.

Sudah menjadi tuntutan para pemilik naskah bahwa naskah yang dikelolanya membutuhkan kertas yang berkualitas tahan lama dan warna kertas tidak cepat memudar. Untuk itu perlu pemahaman kepada pemilik naskah dan pengelola naskah. Peran pengelola dan pengetahuan masyarakat dalam merawat kertas arsip dimulai dari penciptaan naskah, penggunaan naskah, dan penyusutannya. Kebutuhan akan pengetahuan tentang perawatan naskah sudah menjadi kebutuhan pokok yang harus di kuasai oleh pemilik naskah atau pengelola naskah, dengan demikian perawatan naskah kuno yang terbuat dari bahan kertas dapat dilakukan secara maksimal. Juga faktor-faktor penyebab kerusakan kertas harus sudah di ketahui, agar dalam menentukan metode dan prosedur dalam hal merawat naskah yang terbuat dari bahan kertas dapat efektif dan juga efisien dalam hal pembiayaan.

Naskah kuno yang tergolong vital sebaiknya menggunakan kertas-kertas yang berkualitas tinggi, artinya kertas itu tidak mengandung asam. Kertas yang baik adalah kertas yang bebas asam atau mempunyai $\mathrm{pH}$ 7. Ukuran $\mathrm{pH}$ dapat diketahui dengan menggunakan $\mathrm{pH}$ meter. Untuk ukuran satuan $\mathrm{pH}$ dimulai dari 1-14. Jika kertas mengandung $\mathrm{pH}$ kurang dari 7, maka kertas itu mengandung asam. Sedangkan $\mathrm{pH}$ diatas 7 , maka kertas tersebut mengandung alkalin. Arsiparsip di sebelum abad ke-19 banyak menggunakan bahan kertas yang memiliki pH rata-rata 6,9, tetapi setelah abad ke-19 bahan kertas yang digunakan untuk arsip memiliki kandungan $\mathrm{pH} 5,4$, jadi semakin rendah $\mathrm{pH}$ nya maka semakin tinggi pula tingkat ke asaman kertas tersebut. Dengan semakin tingginya asam pada kertas, semakin cepat pula kerusakan yang terjadi pada kertas tersebut.. Sehubungan dengan masalah kerusakan arsip yang terbuat dari kertas, dibutuhkan pula pusat laboratorium untuk meneliti kandungan asam yang ada pada kertaskertas arsip.

Di laboratorium semua bahan kertas dapat diuji kandungan zat asam yang terdapat di kertas arsip. Pengujian kertas arsip ini penting dengan tujuan preservasi arsip konvensional dan media baru. Pengujian bahan atas kerusakan tersebut dapat dilakukan pada skala laboratorium. Beberapa hal yang perlu dikaji antara lain:

a. Pengujian dan kualitas dari mutu dan kelengkapan dari naskah tersebut

b. Melakukan pengujian kertas pada suatu naskah perlu tidaknya sebuah naskah kuno direstorasi atau dikembangkan.

c. Pengujian bahan untuk bahan pemeliharaan, restorasi dan produksi ulang naskah

d. Pengujian ulang hasil restorasi dan reproduksi naskah kuno agar bisa dilestarikan.

e. Pengujian otentisitas naskah kuno. 


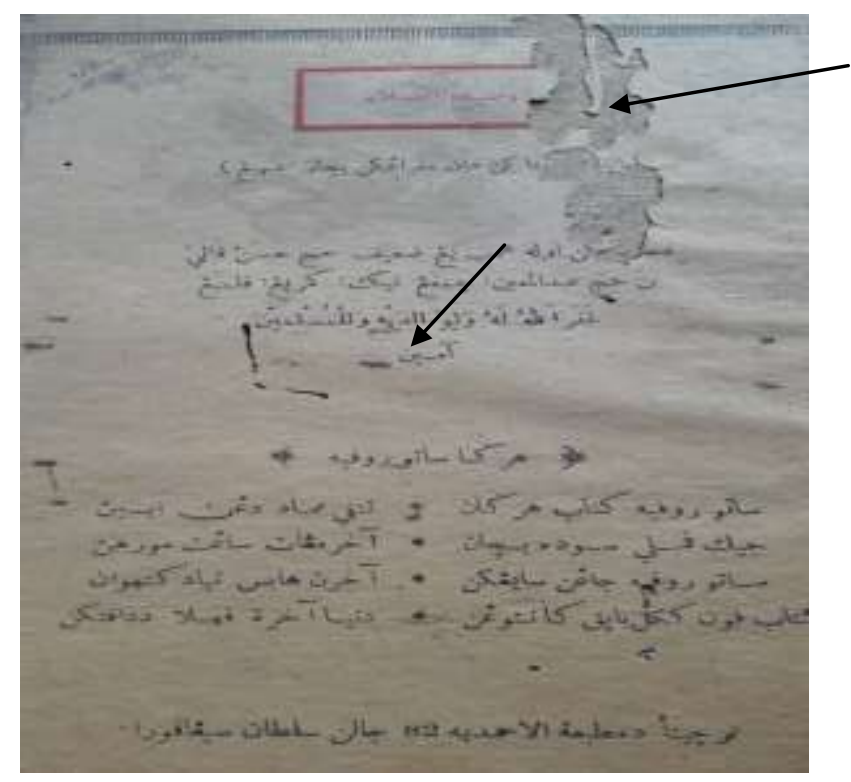

Gambar 10. Kerusakan naskah dimakan rayap dan lapuk karena jamur

Rusaknya naskah dapat juga disebabkan oleh biota lainnya seperti jamur. Terlihat pada cetakan akan tumbuh pada bahan pembawa organik yang memberikan nutrisi yang sesuai, termasuk kertas, perekat, bookbindings, mikrofilm, slide, kaset video, debu, dll. Buku dan kertas terutama menyediakan habitat yang sempurna untuk jamur tumbuh berkembang karena bersifat higroskopis dan menyerap dan menahan Kelembaban. Jamur di perpustakaan menunjukkan bahwa telah terjadi peningkatan kelembaban relatif

\section{Faktor-Faktor Penyebab Kerusakan pada Naskah Kuno}

Selain faktor serangga dan biota, kerusakan naskah kuno dapat disebabkan oleh faktor lingkungan. Dalam ekologi dikenal dengan faktor-faktor abiotik. Faktor abiotik akan mempenagruhi faktor biotik dalam hal ini serangga dan jamur yang dapat hidup pada lembar naskah kuno tersebut. Hasil pengukuran dilapangan terhadap faktor abiotik pada tempat penyimpanan dan kondisi naskah yang ditemukan menggunakan alat $\mathrm{pH}$ meter dengan kertas indikator $\mathrm{pH}$, termometer air raksa untuk suhu. Kelembaban dengan alat digital. Hasilnya dapat dilihat pada Tabel 1 berikut ini:

Tabel 1. Hasil Pengukuran Faktor Abiotik terhadap Naskah kuno yang ditemukan

\begin{tabular}{|l|l|c|c|c|}
\hline No & Faktor Abiotik & Masyarakat & Musium & Ideal \\
\hline 1 & $\begin{array}{l}\text { Suhu Lemari } \\
\left(\text { Penyimpanan) }\left({ }^{\circ} \mathrm{C}\right)\right.\end{array}$ & 30 & 32 & $20-24$ \\
\hline 2 & Suhu ruang $\left({ }^{\circ} \mathrm{C}\right)$ & 20 & 30 & $30-34$ \\
\hline 3 & Cahaya $(\mathrm{lx})$ & 160 & 400 & $300-400$ \\
\hline 4 & pH kertas & 4 & 6 & $6,5-7$ \\
\hline
\end{tabular}

Pengukuran faktor abiotik Tabel 1 pendukung terjaganya naskah kuno dari serangan serangga perusak dan jamur. Hasilnya terlihat bahwa, suhu 
penyimpanan di rumah masyarakat dan musium lebih tinggi dari pengukuran faktor abiotik yang ideal. Preservasi naskah dari serangan serangga dapat dilakukan dengan pemeliharaan fisik naskah maupun teks dalam naskah. Oleh karena itu preservasi bertujuan untuk konservasi naskah. Konservasi ini sebagai upaya untuk memperpanjang usia naskah. Oleh karena itu faktor fisik harus diperhatikan, usaha lain adaah dengan fumigasi, kemudian disimpan dalam ruang khusus dengan suhu $16^{\circ} \mathrm{C}$ selama 24 jam. Kelembaban udara juga diatur antara $50-55 \%$. Kemudian baru dilakukan restorasi merawat dan mengembalikan keutuhan naskah, sehingga diharapkan bisa bertahan lebih lama ${ }^{10}$.

Dari hasil penelitian yang didapatkan, kerusakan naskah selain oleh faktor biotik, juga disebabkan oleh faktor abiotik. Faktor biotik merupakan faktor yang disebabkan oleh organisme (biota serangga dan mikroba/organise kecil lainnya). Faktor abiotik secara umum dibagi 2 yaitu faktor alamiah dan faktor manusia. Faktor abiotik secara secara fisik alamiah disebabkan oleh faktor fisik dan kimia lingkungan. Pengetahuan tentang faktor penyebab ini menjadi penting saat digunakan untuk konservasi dan restorasi.

Mengetahui macam-macam perusak naskah atau bahan pustaka adalah sama pentingnya dengan memiliki bahan pustaka tersebut. Begitu pula cara memperbaiki bahan pustaka yang rusak. Pengetahuan tentang kerusakan bahan pustaka sudah dikenal sejak tahun $335 \mathrm{SM}$ oleh Aristoteles. Daerah tropis memiliki berbagai perusak bahan pustaka seperti dijelaskan oleh Plumbe. Pada dasarnya kerusakan bahan pustaka dipengaruhi oleh beberapa faktor yaitu: faktor biologi (binatang pengerat, serangga dan jamur), faktor fisika dan faktor kimia. Selain itu faktor yang dapat menyebabkan kerusakan bahan pustaka adalah faktor alam, seperti sinar matahari, banjir, gempa bumi, atau api serta manusia. Selain manusia dan hewan, debu, jamur, zat kimia dan alam semesta juga bisa merusak bahan pustaka. Agar bahan pustaka tidak lekas rusak, setiap pegawai museum harus mengetahui cara-cara merawat bahan pustaka. Karena itu, setiap pegawai museum tahu menyusun dan merawat bahan pustaka (Purwono, 2010:52).

\section{Identifikasi Serangga yang Ditemukan pada Naskah Kuno}

Identifikasi serangga yang ditemukan pada naskah kuno dengan teknik hand colecting yang dilakukan hasilnya didapatkan 11 jenis serangga yang termasuk kedalam lima ordo dan enam famili. Adapun jenis serangga lainnya terlihat pada Tabel 2 berikut ini:

Tabel 2. Identifikasi serangga yang ditemukan pada naskah kuno

\begin{tabular}{lcc}
\hline No & \multicolumn{1}{c}{ Taksa } & Nama Lokal \\
\hline A & Coleoptera & \\
& Anobiidae & \\
1 & Attagenus megatoma & \\
2 & Chrysopa carnea & Kumbang rokok \\
3 & Lasioderma serricorne & Kumbang biskuit
\end{tabular}

10 Nidafadlan, 2011. Strategi Presrvasi Naskah Kuno dan Pengalaman Digitalisasi. www//nidafadlan.wordpress.com. diakses pada 12 Juni 2017, pukul 21:01 wib. 


\begin{tabular}{|c|c|c|}
\hline 5 & Xestobium rufovillosum & \\
\hline & Blattidae & \\
\hline 6 & Periplaneta americana & Kecoa Amerika \\
\hline 7 & Periplaneta fuliginosa & \\
\hline B & Hymenoptera & \\
\hline 8 & $\begin{array}{l}\text { Formicidae } \\
\quad \text { Formicinae } \mathrm{sp}\end{array}$ & Semut gula \\
\hline $\mathrm{C}$ & Isoptera & \\
\hline 9 & $\begin{array}{l}\text { Cryptotermes } \\
\text { Light }\end{array}$ & Rayap kayu kering \\
\hline $\mathrm{D}$ & Tysanura & pembolong \\
\hline 10 & Thylodrias contractus & kertas \\
\hline $\mathrm{E}$ & $\begin{array}{l}\text { Zygentoma } \\
\text { Lepismatidae }\end{array}$ & \\
\hline 11 & Lepisma saccharina $\mathrm{L}$ & Serangga perakekor ikan \\
\hline
\end{tabular}

Hasil yang didapatkan antara lain lima Ordo dan enam Famili. Jenis yang terbanyak didapatkan adalah jenis kumbang ada tujuh jenis. Hal ini disebabkan banyaknya kertas yang bolong da rusak oleh kumbang-kumbang tersebut. Jumlah jenis yang ditemukan ada 11 jenis dari semua ordo yang hampir ditemukan pada semua pemilik naskah.

\section{Cara Menanggulangi Terhadap Kehadiran Biota dan Serangga Di Tempat Penyimpanan Naskah-Naskah Melayu Palembang}

Serangan serangga perusak naskah dan timbulnya biota lain seperti jamur pada naskah kuno di Palembang tidak terlepas dari cara penyimpanannya. Kebanyakan naskah yang dimiliki oleh pemilik naskah masih secara tradisional. Berbeda jika penanganan naskah tersebut dilakukan oleh pihak lembaga pemerintah seperti musium atau arsip atau perpustakaan pelayanan akan lebih baik dan modern.

Penanggulangan terhadap pelestarian naskah kuno tersebut dapat dilakukan dengan berbagai cara seperti konservasi dan lain sebagainya. Menurut ThorndikeBarnhart, Konservasi adalah "A preserving from harm or decay, protecting from loss or from being used up". Maka dari keterangan tersebut dapat diambil kesimpulan bahwa perkataan konservasi mempunyai pengertian sebagai suatu tindakan untuk melindungi dari bahaya atau kerusakan, memelihara atau merawat sesuatu dari gangguan, kemusnahan, atau keausan ${ }^{11}$. Sjajar dengan pengertian di atas, seperti halnya dengan istilah: "Wild-life conservation", dengan uraian selanjutnya sebagai berikut: "conservation means not only the preservation and protection of natural resources but also their wise use" ${ }^{\text {"12 }}$. Dari uraian ini, pengertian konservasi sangat luas dan umum jangkauan objeknya. Jadi kata konservasi dapat berarti untuk semua objek yang terdapat di alam ini.

\footnotetext{
${ }^{11}$ Herman, 1989:3.

${ }^{12}$ Encyclopedia Britanica vol. 23, 1968: 600).
} 
Naskah yang tergolong ke dalam jenis dokumen maka dikenal dengan istilah pelestarian bahan pustaka (dokumen). Pada hakikatnya kata konservasi dan preservasi memiliki arti yang sama yakni pelestarian yang berasal dari bahasa Inggris yakni Conservation and Preservation. Dalam kamus Inggris-Indonesia yang disusun oleh John M. Echols dan Hasan Shadily, kedua kata ini mempunyai arti yang hampir sama. Konservasi berarti perlindungan, pengawetan, sedangkan preservasi artinya pemeliharaan, penjagaan dan pengawetan.

\section{KESIMPULAN}

Kondisi lingkungan yang kurang mendukung dapat menyebabkan serangga dan biota serta mikroorganisme lainnya dapat tumbuh dan berkembang dengan baik, dimana bahan naskah yang berbahan dasar kertas merupakan nutrien yang baik bagi sebagian serangga dan biota lainnya untuk pertumbuhan hewan dan biota. Hal ini disebabkan karena bahan naskah terbuat dari kertas mengandung zat selulosa sebagai bahan kaya dengan karbohidrat. Pada saat penelitian hampir semua naskah kuno Palembang terbuat dari kertas dengan tempat penyimpanan yang belum memiliki standar yang baik.

Dari hasil penelitian dan analisis pembahasan yang telah dilakukan dapat diambil kesimpulan sebagai berikut:

1. Bentuk dan jenis kerusakan pada naskah kuno Palembang ada dua yaitu kerusakan oleh serangga dengan bentuk kerusakan berupa terbentuknya lubang pada naskah dengan cara menggerek oleh kumbang, rusak dimakan oleh rayap, lapuk oleh karena zat kimia dalam hal ini tinta yang digunakan, bercak hitam karena kotoran kecoa, dan bercak putih dan keabu-abuan, karena jamur yang tumbuh pada kertas naskah tersebut. Secara kuantitatif persentase naskah kuno yang rusak sebesar $80 \%$ naskah rusak yang disebabkan oleh serangga dan biota jamur.

2. Faktor-faktor yang ditemukan penyebab kerusakan pada naskah kuno di Palembang antara pemilik naskah kuno secara pribadi dan lembaga berbeda. Secara umum faktor yang menyebabkan kerusakan pada naskah faktor fisik yaitu kelembaban, suhu ruangan, tempat penyimpanan, cahaya, sedangkan faktor kimia yaitu $\mathrm{pH}$ kertas, tinta yang kuat dan sifat acis menyebabkan kertas seperti terbakar, air.

3. Jenis serangga dan biota yang merusak naskah-naskah kuno di Palembang yang ditemukan dengan metode hand colecting antara lain adalah: 1) Attagenus megatoma, 2) Chrysopa carnea, 3) Lasioderma serricorne, 4) Stegobium paniceum, 5) Xestobium rufovillosum, 6) Periplaneta americana, 7) Periplaneta fuliginosa, 8) Thylodrias contractus, 9) Lepisma saccharina L 10) Formicinae dan 11) jamur

4. Penanggulangan terhadap kehadiran biota dan serangga di tempat penyimpanan naskah-naskah melayu Palembang antara lain dengan cara penyimpanan yang memiliki area tembus cahaya yang masuk kedalam rumah tempat penyimpanan naskah terbatas, sehingga menyebabkan kelembaban tinggi. Selain itu sirkulasi udatra tempat penyimpanan, Temperatur ruang yang ideal bagi bahan naskah adalah 20-24 derajat C dan 45-60\% RH. Satusatunya cara untuk mendapatkan kondisi itu adalah dipasang AC-24 jam 
sehari selama 7 hari dalam seminggu yang dapat diatur pemakaiannya. Memiliki tempat box penyimpanan yang bebas dari zat kimia. Tidak menggunakan bahan plastik yang tidak dapat di kontrol panas udara didalamnya. Penggunaan Bahan kimia, Memiliki Oven untuk proses sterlisasi atau pemanasan naskah, agar tetap terjaga kondisinya. Faktor-faktor dan proses-proses penyebab kerusakan naskah antara lain Rayap, Serangga kayu pemakan selulosa, Larva, Telur, Fungi.

\section{Ucapan terima kasih}

Penelitian ini telah didanai oleh DIPA UIN Raden Fatah Palembang tahun 2017, dalam kesempatan ini penulis mengucapkan terima kasih kepada pimpinan UIN Raden Fatah dan Ketua LP2M atas bantuannya. Kepada semua pihak yang telah membantu terlaksananya penelitian ini penulis mengucapkan terima kasih.

\section{DAFTAR PUSTAKA}

Anonim, Undang Undang No. 5 Tahun 1992, tentang Cagar Budaya, Bab I Pasal 2.

Apostel, Richard and Boris Raymond. 1997. Librarianship and the Information Paradigm. (London: The Scarecrow Press).

Astuti, F.A. 2010. "Studi Tentang Pelestarian Naskah Kuno Dan Penanggulangannya di Perpustakaan Dewantara Kirti Griya Taman Siswa Yogyakarta" Sripsi Jurusan Ilmu Perpustakaan Dan Informasi Fakultas Adab Dan Ilmu Budaya UIN Sunan Kalijaga Yogyakarta.

Borror, Donald. J., Charles A. Triplehorn, Norman F. Jonhson. 1996. Pengenalan Pelajaran Serangga (Yogyakarta: Gadjah Mada Press).

Booth, R.G., M.L.Cox., R.B. Madge, 1989. IIE Gudes to insect of Importance to Man: 3. Coleoptera. Intern. Insitute of Entomology, The Natural History Museum, London. 384 hal.

Buckland, M. 2001. Redesiging Library services: A manifesto. (New York: American Library Association).

Bros, G. 1998. Monitoring Insect Pests With Sticky Traps. Washington. J. Entomol. 3(7): 19-21.

Cabrera, B. J. 2011. Cigarette Beetle, Lasioderma serricorne (F.) (Insecta: Coleoptera: Anobiidae). J. Entomol. Nematod. 1(3): 1-5.

Dalyanto, E. 2006. Atraktan Perangkap lalat dari Protein Hidrolisat Limbah Ikan. Sripsi. IPB. Bogor.

Chapman, R.N. 1939. Insect Population Problem In Relation To Insect Outbreak. Ecol. Monogr. 9 (3) : 261 - 269.

Clay, T. 1970. The Amblycera (Phthiraptera: insect), Bull. Brit. Mus. (Nat. Hits). Entomo. 25: 73-98).

Dewi, D.P. .2014. "Preservasi Naskah Kuno: (Studi Pada Perpustakaan Reksa Pustaka Pura Mangkunegaran Surakarta)". Tesis Konsentrasi Ilmu 
Perpustakaan Dan Informasi Program Pascasarjana UIN Sunan Kalijaga Yogyakarta.

Ebadollahi, E., M. H. Safaralizadeh., A. Pourmirza, dan S. A. Gheibi. 2010. Toxicity of essential Oil of Agastache foeniculum (Pursh) Kuntze to Oryzaephilus surinamensis L. and Lasioderma serricorne F. J. Plant. Protec. Res. 50(2): 215-219

Emerson, K. C. 1972. Checklist of the Mallophaga of North America (North of Mexico). Part I: Suborder Ischnocera, 200 hal. Part II: Suborder Amblycera, 118 hal. Part III: Mammal host list, 28 hal. Part IV: Bird Host List, 216 hal. Dugway, Utah: Dessert Test Center.

Emerson, K, C, dan R D, Price. 1981. A Host vparasite list of the Mallophaga on mammals. Misc, Pulb, entomol. Soc, Amer. 12(1): 1- 72.

Edwing, H. E. 1924. Taxonomy, biology, and distribution of the Gryopidae. Proc. U. S. Natl. Mus. 63 (20): 1-42

Eding, H. E. 1929. A maual of ekcternal parasites. Springfield, III: Charles C. Thomas, 225 hal; bergambar. (Terutama Bab 4., hal 127- 152),

Erwin, 2000. Hama dan Penyakit Tembakau Deli. Balai Penelitian Tembakau Deli, PTPN II, Medan.

Feener, R.M. 2015. "Abd al-Samad in Arabia: The Yemeni Years of a Shaykh from Sumatra", Southeasth Asian Studies Vol. 4 No. 2 (Singapore: Center For Southeast Asian Studies Kyoto University (2015), hlm. 259-277. http://hdl.handle.net/2433/199719.

Ferris, G. F 1919- 1933. Contribution toward a monograph of the sucking lice. Stanford Univ. publ, Biol, Sci. 2:1- 644; bergambar.

Gaur, Albertine. 1975 Writing Materials of The East. London: The British Library

Graham, S.A. dan F.B Knight, 1967. Principles Of Forest Entomology. McGraw-Hill book company. New York, USA

Hardjoprakoso, M. 1997. Buku dan Perpustakaan. Buku Membangun Kualitas bangsa: Bunga rampai sekitar perbukuan di Indonesia. Yogyakarta: Kanisius.

Hopkins, G. H. E, dan T. Clay. 1952. A check List of the Genera and species of Mallophaga. London: Brittish Museum (Nat. Hits,) 362 hal.

Ikram, A. Dkk.1997 Filologi Nusantara. Jakarta: Pustaka Jaya

Imai, T. dan H. Harada. 2006. Low-temperature as an alternative to fumigation to disinfest stored tobacco of the cigarette beetle, Lasioderma serricorne (F.) (Coleoptera: Anobiidae). J. Appl. Entomol. Zool. 41 (1): 87-91.

Jusuf, J. 1983. Naskah sebagai Sumber Sejarah. Jakarta: Proyek Pengembangan Museum Nasional Jakarta.

Jones, Russel.1983 The Origin of Malay Manuscript Tradition in Grijn, C.D. \& S.O. Robson, eds. Cultural Contact and Textual Interpretation, Paper from the Fourth European Colloqium on Malay and Indonesian Studies held in Leiden in 1983, p. 121--143. Dordrecht-Holland/Cinnaminson-USA: Foris Publications.

Kaplan, David. dan Albert A. Manners 2002 Teori Budaya. Jakarta: Pustaka Pelajar.

Kartasapoetra, 1991. Hama Hasil Tanaman Dalam Gudang, Rineka Cipta, Jakarta. 
Kasbolah, K. 1992. Studi Kepustakaan dalam Forum Penelitian 4( 1\&2): 785Lubis. Nabilah, 2007. Teks Naskah, dan Metode Penelitian Fililogi. Jakarta: Puslitbang Lektur Keagamaan Depag RI.

Kim, K, C, (Ed). 1985. Coevolution of parasitic arthropods and mammals, New York: Wiley, 800 hal; bergambar.

Kim, K. C. 1987. Order Anoplura, hal. 224- 245 dala, F. W. Stehr (ed), Immature Insects. Dubuque, lowa: Kendall1/ hunt.; bergambar.

Kim, K. C. dan H. W. Ludwig. 1978a. The Family classification of the Anoplura. Syst. Entomol. 3: 249- 284; bergambar

Kim, K. C. dan H. W. Ludwig. 1978b. Phylogenetic rekationships of parasitic Psocodea and taxonomic position of the Anoplura. Ann. Entomol. Soc. Ammer. 71: 910- 922; bergambar

Kim, K. C. dan H. W. Ludwig. 1982. Parallel evolutioncladistics, and classification of parasitic Psocodea. Ann. Entomol. SDoc. Amer. 75: 537548; bergambar

Kim, K. C. dan H. D, Pratt, dan C. J. Stojanovich. 1986. The sucking lice of Nort America. University park: Pennsylvania State University Press. 241 hal; bergambar

KKBI, 1996. Kamus Besar bahasa Indonesia. (Jakarta: Balai Pustaka).

Mulyadi, Sri Wulan Rujiati. 1994. Kodikologi Melayu di Indonesia, Lembar Sastra Edisi Khusus No. 24. Depok: Fakultas Sastra Universitas Indonesia.

Odum, Eugene P., 1998. Foundamental of Ecology. Tokyo, Japan: Saunders Company.

Painter, R.H., 1951. Insect Resistence In Crop Plants. The Mac Millan Company. New York, USA

Permadi, T. 2011. Naskah Nusantara dan Berbagai Aspek yang Menyertainya. Artikel. http://www.file.upi.edu. Diakses pada Sabtu, 03 Juni 2017 pada pukul 06:07WIB.

Price, R. D. 1987. Order Mallophaga, hal. 215- 223 dalam F. W. Stehr (ed.) Immature Insect Dubuque, lowa: Kendall/ hunt, 754 hal: bergambar.

Roll, D. 2009., General Pest Control. Catetory 10A. A Study Guide for Commercial Applicators. Pesticide and Fertilizer Regulation, Ohio. J. Agric. 3(1): 52-53.

Ross H. Arnett. 2000. American Insects: A Handbook of the Insects of America North of Mexico.. CRC Press. Meksiko

Rukmi, Maria Indra. "Penyalinan Naskah Melayu Palembang: Upaya Mengungkap Sejarah Penyalinannya", dalam Jurnal Wacana Volume 7 No. 2 Tahun 2005, hlm. 149-160.

Scheper, K. 2013. Three very specific binding features, shedding new light on Islamic manuscript structures. Journal of Islamic Manuscripts, vol. 4,(1) pp. 82-109. 
Sutrisno, S. 1981. Relevansi Studi Filologi. Pidato pengukuhan Guru besar dalam bidang Filologi UGM. Yogyakarta.

Tim Penyusun, Katalog Naskah Palembang, (Jakarta: Yayasan Naskah Nusantara (Yanassa) dan Tokyo University of Foreign Studies (TUFS) Jepang, 2003).

Wirayati, M.A., Ellis S.A., dan Aris Riyadi. 2013. Pedoman Teknis Pembasmian Serangga dan Biota di Perpustakaan. Jakarta: Perpusnas RI.

Werneck, F, L. 1848- 1950. Os Malopfagos de Mamiferos. Parte I: Amblycera e Ischnocera (Philopteridae e parte de Trichodectidae), 243 hal. (1948). Parte II: Ischnocera (continuacao de Trichodejaneiro: Edicao de Revista Brasileira de Bioloogia.

Yusuf, A. Muri. 2015. Metode Penelitian: Kuantitatif, Kualitatif dan Penelitian gabungan (Jakarta: Prenada media group) hal 63-65.

Zulkifli, Ulama Sumatra Selatan : Pemikiran dan Peranannya Dalam Lintasan Sejarah. (Palembang: Unsri Press, 1999), hlm. 11-40. 